\title{
Study on Crack Resistance of Hydraulic Roller Compacted Concrete Dam with Fly Ash Admixture
}

\author{
Xiaogang $\mathrm{Li}^{1}$ \\ ${ }^{1}$ China Northwest Water Conservancy \& Hydropower Engineering Consulting Co., Ltd., Xi 'an, 710100, China
}

\begin{abstract}
With the continuous improvement of the level of construction industry in modern industry, at the same time, the requirements of the construction industry for the crack resistance of concrete dams are also higher and higher. In the preparation stage of the experiment, the corresponding experimental materials and equipment are provided. In order to ensure that the concrete can meet the requirements of workability and strength grade, the proportion of materials is designed; During the experiment, the activity characteristics of fly ash admixture are extracted, the particle size distribution of admixture is tested, and the fracture data of hydraulic RCC dam is monitored; The experimental results show that when the ratio of cement and fly ash is 0.7:0.1, the number, width and area of concrete cracks are the minimum, which proves that the fly ash admixture under this ratio is more suitable for construction engineering.
\end{abstract}

\section{Introduction}

With the development of concrete science, it is no longer difficult to prepare concrete with high strength and good working performance ${ }^{[1]}$. People gradually shift the focus of research to the durability of concrete. Whether concrete can be used as one of the most important building structural materials for a long time depends on whether it can become a high durability and environment-friendly green material ${ }^{[2]}$. The early cracking of concrete structure is a common phenomenon in engineering. The practice shows that the early cracking phenomenon of concrete has become a research hotspot in the field of concrete technology at home and abroad. The existing researches mainly focus on the volume stability and cracking of hardened concrete, and have made many achievements. The crack resistance of concrete is one of the most important performance indicators, which directly affects its application. Improving the crack resistance of concrete has always been the goal pursued by people ${ }^{[3]}$. How to improve the crack resistance of concrete is a very important project, which involves many aspects such as design scheme, construction technology, material selection, etc. the concrete mix proportion design is the basis of durability research, and the design objective of concrete mix proportion has changed from single strength index design to multi-objective design of workability, strength, crack resistance and durability.

\section{Experimental preparation}

\subsection{Preparing experimental materials and equipment}

Concrete is a general term for composite materials that aggregate is cemented into a whole by cementitious materials. According to the different cementitious materials can be divided into cement concrete, asphalt concrete, polymer concrete, etc. Among them, cement concrete is the most widely used and used building material in construction engineering ${ }^{[4]}$. The application of cement concrete can be traced back to the invention of Portland cement in the early 19th century. In the early stage, due to the need of mixing and pouring performance, the cement concrete with high water cement ratio and low strength was mostly used in engineering. However, the weakness of low tensile strength and poor crack resistance of concrete has not been improved ${ }^{[5]}$. In addition, compared with the low strength concrete, the hydration of high strength concrete consumes more water, and the water diffusion coefficient is smaller, so the internal humidity is more uniform, and the degree of uneven shrinkage is smaller ${ }^{[6]} . \mathrm{C} 30, \mathrm{C} 50$ and $\mathrm{C} 80$ are selected as the research objects, which represent ordinary concrete, medium high strength concrete and high strength concrete respectively. The experimental equipment is shown in Table 1. 
Table1. Experimental equipment

\begin{tabular}{|c|c|c|c|}
\hline $\begin{array}{l}\text { numbe } \\
\mathrm{r}\end{array}$ & name & Manufacturer & model number \\
\hline 1 & $\begin{array}{l}\text { Microcompute } \\
\mathrm{r} \text { controlled } \\
\text { electronic } \\
\text { universal } \\
\text { testing } \\
\text { machine }\end{array}$ & $\begin{array}{l}\text { China } \\
\text { Building } \\
\text { Materials } \\
\text { Equipment } \\
\text { Corporation }\end{array}$ & RGM-100A \\
\hline 2 & $\begin{array}{l}\text { Automatic } \\
\text { mercury } \\
\text { porosimeter }\end{array}$ & $\begin{array}{l}\text { Shanghai } \\
\text { future } \\
\text { experimental } \\
\text { equipment } \\
\text { Co., Ltd }\end{array}$ & $\begin{array}{l}\text { AutoPoreIV95 } \\
00\end{array}$ \\
\hline 3 & $\begin{array}{l}\text { Automatic } \\
\text { elastic } \\
\text { modulus tester }\end{array}$ & $\begin{array}{l}\text { Hebei } \\
\text { Dahong Test } \\
\text { Instrument } \\
\text { Co., Ltd }\end{array}$ & DTW18 \\
\hline 4 & $\begin{array}{l}\text { scanning } \\
\text { electron } \\
\text { microscope }\end{array}$ & $\begin{array}{l}\text { Hitachi } \\
\text { Manufacturin } \\
\text { g Co., Ltd }\end{array}$ & S- -4800 \\
\hline 5 & $\begin{array}{l}\text { Concrete } \\
\text { single side } \\
\text { freeze thaw } \\
\text { testing } \\
\text { machine }\end{array}$ & $\begin{array}{l}\text { Yingbei'er } \\
\text { (Tianjin) } \\
\text { measurement } \\
\text { and control } \\
\text { equipment } \\
\text { Co., Ltd }\end{array}$ & IMYD-10 \\
\hline 6 & $\begin{array}{l}\text { Forced single } \\
\text { horizontal } \\
\text { shaft concrete } \\
\text { mixer }\end{array}$ & $\begin{array}{l}\text { Shanghai } \\
\text { Luda Testing } \\
\text { Instrument } \\
\text { Co., Ltd }\end{array}$ & SJD \\
\hline 7 & $\begin{array}{l}\text { Cement } \\
\text { concrete } \\
\text { standard } \\
\text { constant } \\
\text { temperature } \\
\text { and humidity } \\
\text { curing box }\end{array}$ & $\begin{array}{l}\text { Hebei } \\
\text { Dahong Test } \\
\text { Instrument } \\
\text { Co., Ltd }\end{array}$ & YH-40A \\
\hline 8 & $\begin{array}{l}\text { Electric blast } \\
\text { drying oven }\end{array}$ & $\begin{array}{l}\text { Tianjin taist } \\
\text { Instrument } \\
\text { Co., Ltd }\end{array}$ & $101-3 \mathrm{AB}$ \\
\hline 9 & $\begin{array}{l}\text { Medical } \\
\text { cryopreservati } \\
\text { on box }\end{array}$ & $\begin{array}{l}\text { Qingdao } \\
\text { Haier Special } \\
\text { Electric } \\
\text { Appliance } \\
\text { Co., Ltd }\end{array}$ & DW-25W388 \\
\hline 10 & $\begin{array}{l}\text { Vertical } \\
\text { omnidirectiona } \\
1 \text { planetary ball } \\
\text { mill }\end{array}$ & $\begin{array}{l}\text { Nanjing } \\
\text { NANDA } \\
\text { Instrument } \\
\text { Factory }\end{array}$ & QM-QX \\
\hline
\end{tabular}

The cement used in the experiment is $\mathrm{P} \cdot \mathrm{O} 42.5 \mathrm{R}$ ordinary portland cement produced by Dalian cement plant, and the cement is placed in a dry and ventilated place to ensure that the cement will not be affected by moisture and caking ${ }^{[7-8]}$. In the process of concrete configuration, adding admixtures can improve the performance of concrete and reduce the cost.

\subsection{Proportion of design materials}

In this test, self mixing pumping concrete is required, and the slump is up to $200 \mathrm{~mm} \pm 20 \mathrm{~mm}$. According to the mix proportion design method of ordinary concrete, the initial mix proportion is calculated, adjusted and trial mixed for many times ${ }^{[9-10]}$, and finally three kinds of strength grade concrete mix proportion with strength value and slump value meeting the requirements are obtained, as shown in Table 2:

Table2. Concrete ratio

\begin{tabular}{llll}
\hline $\begin{array}{l}\text { Dosage per } \\
\text { cubic meter } \\
\left(\mathrm{kg} / \mathrm{m}^{3}\right),\end{array}$ & C30 & C50 & C80 \\
proportion & & & \\
\hline Cement + fly & $354+86$ & $352+44$ & $387+94$ \\
ash & $0.7: 0.3$ & $0.7: 0.1$ & $0.8: 0.2$ \\
Sand & 721 & 716 & 706 \\
& 0.35 & 0.3 & 0.4 \\
gravel & 1082 & 1082 & 1058 \\
& 0.6 & 0.6 & 0.5 \\
water & 220 & 220 & 198 \\
& 0.4 & 0.4 & 0.4 \\
Water & 4.6 & 5.71 & 7.728 \\
reducing & $1 \%$ & $1.3 \%$ & $1.5 \%$ \\
agent & & & \\
Slump & 212 & 200 & 210 \\
7d strength & 20 & 29 & 30 \\
28d strength & 33 & 44 & 56 \\
\hline
\end{tabular}

According to the standard test method, the average 28 day cube compressive strength of C30, C50 and C80 concrete is $33.48 \mathrm{MPa}, \quad 48.36 \mathrm{MPa}$ and $87.33 \mathrm{MPa}$ respectively, meeting the strength requirements.

\section{Experimental process}

\subsection{Extraction of activity characteristics of fly ash admixture}

The core of fly ash has the following basic micro morphology: 1. Spherical particles, including floating beads, composite beads, iron rich micro beads and other basic components. The particle has a more regular external performance, the actual size has a significant difference, the comprehensive surface maintains a relatively smooth shape, belongs to one of the core components of the special dry discharged fly ash. 2 . Irregular porous glass particles, the core of which is the related vitreous material, showing a special basic form of sponge and honeycomb .3 . The obtuse angle core belongs to the special residue of related quartz particles, and there is no basic hydration activity. 4. Fine particles, which belong to relatively small existence, the core belongs to the basic debris of special particles and special aggregates of various particles. 5. Carbonaceous particles, which belong to related regular porous particles, are easy to be broken and then evolve into related porous debris.

\subsection{Testing the particle size distribution of admixtures in hydraulic rolling}

The type and size distribution range of admixtures can affect the related performance of concrete. Therefore, the reasonable selection of admixtures is one of the important preconditions to improve the performance of concrete. Use the sampling spoon to take the right amount of admixture in the beaker with the right amount of distilled 
water, and use the glass rod to stir, so that the diatomite can be evenly dispersed in the water. The formula for calculating the linear expansion coefficient of admixtures is as follows:

$$
Q=D \cdot f\left(\frac{1}{k}\right)+\Delta \varepsilon
$$

In formula (1), $D$ is the elastic modulus, $f$ is the ultimate tensile value, $k$ is the dry shrinkage value, and $\varepsilon$ is the autogenous volume deformation value. But at the same time, the increase of concrete strength and elastic modulus will weaken the creep ability. When the ambient temperature changes, the formula of particle size change is as follows:

$$
R=\frac{v\left(\varphi_{i}+m_{j}\right)}{t}
$$

In formula (2), $v$ is the tensile strength of the admixture, $\varphi$ is the tensile stress of the admixture, $m$ is the tensile strength, $t$ is the stress time, and $i, j$ is the maximum and minimum deflection coefficient respectively. Generally, the higher the ambient temperature of concrete, the greater the creep.

\subsection{Monitoring fracture data of hydraulic RCC dam}

In the constrained ring test, three acoustic sensors are spaced 120 apart $^{\circ}$.It is mounted on the outer or upper surface of the annular specimen. When the shrinkage of concrete is restrained by the steel ring, the tensile strain is generated in the concrete, and then the elastic wave is released. With the continuous shrinkage, the elastic wave increases gradually. When the microcracks are formed and aggregated, the elastic wave increases rapidly. When the micro fracture evolves into a macro fracture, the elastic wave increases suddenly, which shows a sudden rise of the elastic wave curve. In order to quantitatively analyze the influence of specimen size and material parameters and calculate the crack displacement of concrete, the mathematical expression is as follows:

$$
\beta=\frac{W-W \mid Q_{s}}{p} \times 100 \%
$$

In formula (3), $W$ is the shrinkage time of concrete, $Q$ is the displacement ratio of concrete, $S$ is the restraint degree, and $p$ is the shrinkage strain value. In the newly poured concrete, the water is filled in the gap between the cementitious material and the aggregate. In the process of concrete curing, the moisture is consumed by the hydration reaction of cement. At the same time, the moisture diffuses to the dry surface and loses to the environment through the dry surface until the environmental humidity keeps balance with the internal humidity of concrete. According to the water diffusion theory of concrete dam, the moisture presents obvious non-linear distribution along the direction of water diffusion, and the area near the dry surface has fast water loss and large drying shrinkage. In contrast, the area far away from the dry surface of the dam has slow water loss and small drying shrinkage. The non-uniform shrinkage along the direction of water diffusion caused by this will make the area near the dry surface appear larger tensile stress, while the area far away from the dry surface appear smaller tensile stress or even compressive stress. In the newly poured concrete dam, water is filled in the gap between the cementitious material and the aggregate. In the process of concrete dam maintenance, the water is consumed by the hydration reaction of cement. At the same time, the water diffuses to the dry surface and loses to the environment through the dry surface until the environmental humidity keeps balance with the internal humidity of concrete. Among the fracture properties of concrete, fracture energy is a key parameter. The formula of fracture energy is as follows:

$$
F=\frac{U_{0}+\frac{1}{2} l \cdot \theta_{\text {max }}}{y}
$$

In formula (4), $U_{0}$ is the integral area under the displacement curve of the loading point, $l$ is the weight of the concrete, $\theta$ is the maximum displacement of the dam loading point measured, and $y$ is the ligament area of the three-point bending beam specimen. According to the theory of concrete moisture diffusion, the moisture presents obvious non-linear distribution along the direction of moisture diffusion, and the area near the drying surface has fast moisture loss and large drying shrinkage. In contrast, the area far away from the dry surface has slow water loss and small drying shrinkage.

\section{Analysis of experimental results}

The length of the crack is measured with a steel ruler, and the straight-line distance between the two ends of the crack is taken as the crack length. When there are two cracks on a knife edge, the length of the two cracks is added and converted into one crack. The crack width is measured by a comprehensive crack measuring instrument with a magnification of 50 times, and the maximum width of each crack is measured. The average cracking area of concrete specimen is calculated according to the crack data measured 24 hours after concrete pouring. The formula of cracking area of concrete crack is as follows:

$$
\eta=\frac{1}{2 N} \sum_{i=1}^{N}\left(E_{i} \times M_{i}\right)
$$

In formula (5), $N$ is the total number of cracks, $E$ is the flat area, $M$ is the maximum width of cracks, and $i$ is the $i$-th crack. The experiment was carried out at (22 $\pm 1){ }^{\circ} \mathrm{C}$. The relative humidity was $\left(65^{\circ} \mathrm{C}\right) \pm 3$ ) In a constant temperature and humidity chamber; After the concrete is poured into the mold, the concrete is leveled and the surface is slightly higher than the mold frame. Put the mold with concrete on the vibration table to control the vibration time to prevent over vibration and under vibration. After vibration, the concrete surface shall be 
leveled with trowel, and the aggregate shall not be exposed, and the surface shall be smooth. After the specimen is molded for $30 \mathrm{~min}$, adjust the position of the fan and the wind speed immediately, so that the wind speed at $100 \sim$ above the center of the specimen surface is $(4 \pm 0.5) \mathrm{m} / \mathrm{s}$. The wind direction should be parallel to the specimen surface and crack inducer. The experimental time was calculated from the beginning of concrete mixing and adding water \pm 5 ) $\mathrm{H}$. According to the calculation results, the experimental results are shown in Figure 1-3:

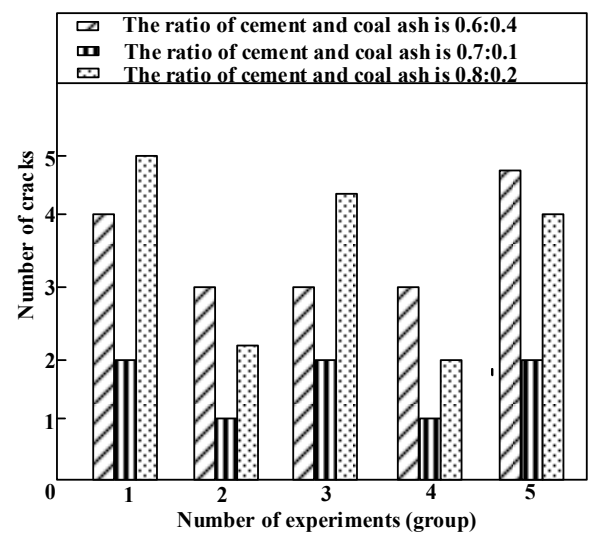

Figure 1. Number of concrete cracks

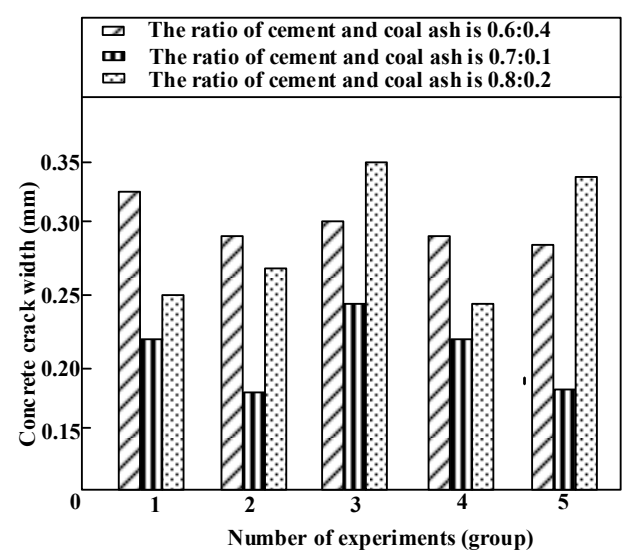

Figure 2. Width of concrete crack $(\mathrm{mm})$

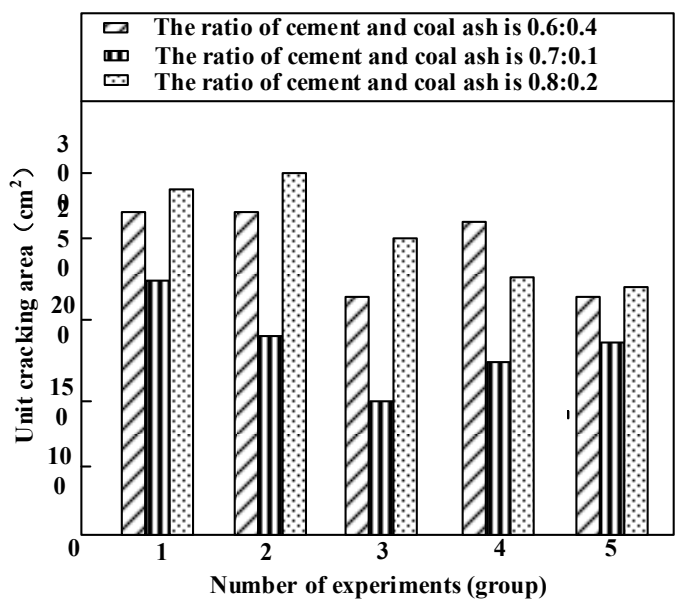

Figure 3. Cracking area of concrete $\left(\mathrm{cm}^{2}\right)$
It can be seen from Figure 1 to figure 3 that when the ratio of cement and fly ash is $0.6: 0.4$, the average number of cracks is about 3 , the average width of cracks is $0.334 \mathrm{~mm}$, and the cracking area is $234.16 \mathrm{~cm}^{2}$; When the ratio of cement and fly ash is $0.7: 0.1$, the average number of cracks is about 2, the average width of cracks is 0.206 $\mathrm{mm}$, and the cracking area is $165.09 \mathrm{~cm}^{2}$; When the ratio of cement and fly ash is 0.8:0.2, the average number of cracks is about 3 , the average width of cracks is $0.328 \mathrm{~mm}$, and the cracking area is $229.31 \mathrm{~cm}^{2}$; The experimental results show that when the ratio of cement and fly ash is $0.7: 0.1$, the crack resistance of concrete is the best.

\section{Conclusion}

This paper studies the crack resistance of hydraulic roller compacted concrete dam with fly ash admixture, and obtains the corresponding experimental results, which enriches the academic literature on admixture and concrete. Due to the limited research conditions, the application research of other types of admixtures in concrete is not thorough enough, and will continue to improve in the future.

\section{References}

1. Thang N C, Tuan N V, Yang K H, et al. Effect of Zeolite on Shrinkage and Crack Resistance of HighPerformance Cement-Based Concrete[J]. Materials, 2020, 13(17):3773.

2. Mizobuchi T, Ishizeki K, Sagawa T, et al. Study on the Influence of Minor Constituents in Blast Furnace Slag Rich Cement on the Thermal and Mechanical Properties of Concrete[J]. Journal of Advanced Concrete Technology, 2019, 17(1):46-61.

3. Weber $\mathrm{M}$, Thiele $\mathrm{C}$. Correlation between compressive and tensile strength of old concretes: Applicability of the relationship described in EN 1992-1-1[J]. Structural concrete, 2019, 20(1):483492.

4. Hassan A, F Khairallah, Elsayed H, et al. Behaviour of concrete beams reinforced using basalt and steel bars under fire exposure $[\mathrm{J}]$. Engineering Structures, 2021, 238(3):112251.

5. Autrup F , Joergensen H B . Shear capacity of RC members without shear reinforcement: A modified crack sliding model[J]. Engineering Structures, 2021, 239(6): 112147.

6. Heek P, Look K, Oettel V, et al. Bemessung von Stahlfaserbeton und stahlfaserbewehrtem Stahlbeton[J]. Beton- und Stahlbetonbau, 2021, 116(S1):2-12.

7. Li S, Zhao X. Automatic Crack Detection and Measurement of Concrete Structure using Convolutional Encoder-Decoder Network[J]. IEEE Access, 2020, PP(99):1-1.

8. Ding Y, Hao X, Men X. Effect of fiber on the crack width, tortuosity and permeability of 
concrete[J]. Fuhe Cailiao Xuebao/Acta Materiae Compositae Sinica, 2019, 36(2):491-497.

9. $\mathrm{X}$ Fan, Liu J , Hu S , et al. Influence of FRP Bonding Length on Fracture Parameters of Concrete Three-Point Bending Beam $[\mathrm{J}]$. Jianzhu Cailiao Xuebao/Journal of Building Materials, 2019, 22(1):38-44.

10. Zhu Z, Tan G, Zhang W, et al. Preliminary Analysis of the Ductility and Crack-Control Ability of Engineered Cementitious Composite with Superfine Sand and Polypropylene Fiber (SSPPECC)[J]. Materials, 2020, 13(11). 